然

Global Journals Inc

8

\title{
Impact of Business Intelligence on Business Performance of Food Delivery Platforms in Sri Lanka
}

\author{
By Kishore Shanmugam, Kabilesh Jeganathan, \\ Mohamed Saif Mohamed Basheer,
} Mohamed Aakib Mohamed Firthows \& Anuradha Jayakody

Abstract- The purpose of this research is to determine if business intelligence has an impact on the business performance of the food delivery platforms in Sri Lanka. An analysis of the 178 responses from the employees of Uber EATS and Pick Me Food concluded that business intelligence has a statistically significant impact on the business performance of the food delivery platform. To understand if external environmental factors have an impact on the business performance of food delivery platforms, a sample of 379 customer responses analyzed, and it statistically proved that there is an impact, as well as the Global Pandemic of Covid-19 also impacted the food delivery platforms, Still, they managed to overcome them through identifying a new business opportunity. This research paper also goes through the Business Intelligence tools and methods used.

Keywords: business intelligence, business performance, COVID-19, food delivery platform.

GJMBR-G Classification: JEL Code: MOO

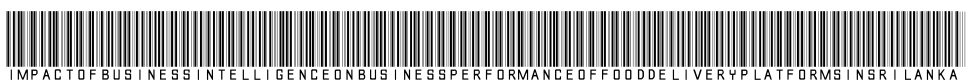

Strictly as per the compliance and regulations of:

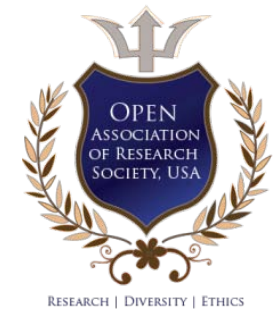

(C) 2020. Kishore Shanmugam, Kabilesh Jeganathan, Mohamed Saif Mohamed Basheer, Mohamed Aakib Mohamed Firthows \& Anuradha Jayakody. This is a research/review paper, distributed under the terms of the Creative Commons AttributionNoncommercial 3.0 Unported License http://creativecommons.org/licenses/by-nc/3.0/), permitting all non-commercial use, distribution, and reproduction in any medium, provided the original work is properly cited. 


\title{
Impact of Business Intelligence on Business Performance of Food Delivery Platforms in Sri Lanka
}

\author{
Kishore Shanmugam ${ }^{\alpha}$, Kabilesh Jeganathan ${ }^{\sigma}$, Mohamed Saif Mohamed Basheer ${ }^{\rho}$, \\ Mohamed Aakib Mohamed Firthows ${ }^{\omega}$ \& Anuradha Jayakody ${ }^{*}$
}

Abstract- The purpose of this research is to determine if business intelligence has an impact on the business performance of the food delivery platforms in Sri Lanka. An analysis of the 178 responses from the employees of Uber EATS and Pick Me Food concluded that business intelligence has a statistically significant impact on the business performance of the food delivery platform. To understand if external environmental factors have an impact on the business performance of food delivery platforms, a sample of 379 customer responses analyzed, and it statistically proved that there is an impact, as well as the Global Pandemic of Covid-19 also impacted the food delivery platforms, Still, they managed to overcome them through identifying a new business opportunity. This research paper also goes through the Business Intelligence tools and methods used.

Keywords: business intelligence, business performance, COVID-19, food delivery platform.

\section{InTRODUCTION}

T he food delivery industry is a booming industry with an enormous business opportunity for both third party FDP, and restaurant chain, which have a separate delivery system with potential market size of $\$$ 210 billion in the US, and the Food delivery business like Eat street and Grub hub offers delivery for the many types of establishments. There, and are startups like Blue apron uses consumer preference to sell fresh food which doesn't require more preparation for delivery [1]. This study will investigate the impact of Business Intelligence $(\mathrm{BI})$ on the business performance (BP) of the Food Delivery Platform (FDP) in Sri Lanka. Because $\mathrm{Bl}$ is becoming an integral part of many companies, especially in FDPs' since many data are being received and it can be used properly with the help of BI. Also, this study will help to understand the impact of external environmental factors, in terms of the customers' perception towards the business and Covid-19 outbreak, and how that impacted the BP of these delivery platforms.

These delivery services have started to penetrate all forms of businesses, from small local restaurants to large international restaurants. Customers' needs are vast, and their lifestyle keeps

Author a $\sigma \rho \omega ¥:$ e-mails: Kishoreshan2801@gmail.com,

Jeganathan.kabilesh@gmail.com, saifbasheer96@gmail.com,

Aakib.fm@gmail.com, anuradha.j@sliit.lk changing, to satisfy and cope with these changes, all these different kinds of restaurants have to be covered. These delivery businesses will have to compete in the market within each other's in terms of delivery time, availability, service quality, and other factors that will affect their customers. Online food delivery market penetration stroked at 30\% in 2016 and expected to be growing further as the market started to mature, reaching $65 \%$ per year [2].

When customers use the applications to order food, their data, which generated daily is massive and could be used in their respective delivery business to give them a competitive advantage. With $\mathrm{Bl}$, these businesses could give personalized services to each customer in the form of offers for their favorite restaurants, reduction of delivery charges, and so on, to retain them. Worldwide $\mathrm{Bl}$ total revenue is said to drastically increase to $\$ 40+$ billion by this year (2020). BI and its analytics will be important in supporting the rapid growth of data outside and within the organization as well [3].

\section{a) Problem Statement}

There are several online FDPs' existing in Sri Lanka that are using $\mathrm{BI}$ in their organization, and the impact that the $\mathrm{BI}$ has on $\mathrm{BP}$ on these FDPs' remains unknown. Uber EATS have delivered three million orders to Sri Lankans and single-handedly dominated the market from 2018 to 2019 [4]. All the previous research was done in $\mathrm{BI}$ and FDP separately, despite having a complete understanding of the data and $\mathrm{Bl}$ tools \& methods used to provide insights and solutions for these platforms is vital to sustain their market share and increasing revenue.

During this Global pandemic situation of the Covid-19 virus outbreak, Uber and Pick Me both the taxi services and FDP have been operating under government regulations. [5]. Uber EATS and Pick Me food have also partnered with other businesses to distribute essential products such as Groceries, pharmaceutical products, and fresh vegetables \& fruits. 
b) Research Objectives

a. Main Objective

- To determine if $\mathrm{BI}$ has an impact on BP of FDPs' in Sri Lanka.

This objective will help to find how does the BI has an impact on FDPs' BP and how it helps the industry's betterment.

b. Sub Objective

- To understand the impact of Strategic planning, Organizational Support, Knowledge Management, and Technological Innovation on BP.

- To identify the $\mathrm{BI}$ methods and tools is used by FDPs' in Sri Lanka.

- To identify the effect that external environmental factors have on BP.

\section{c) Significance of the study}

The significance of the study can be the academic and practical implications for this study. As per the academic implication for this study, the study can be used for future research for a better understanding of how Business intelligence can be used to improve organizational performance and can be used as literature for the application of the food delivery platform.

Whereas per the practical implication of the study is where this study can be used by the food delivery platform where the organization can use this to improve their BI Framework and helps the food delivery platforms without $\mathrm{Bl}$ to implement $\mathrm{BI}$ System and help an entrepreneur who is planning start business in Food delivery industry for $\mathrm{Bl}$ implementation in terms of Business intelligence implementation in the organization.

\section{LITERATURE REVIEW \& CONCEPTUAL FRAMEWORK}

The literature review for this research has been divided into three different sections, such as $\mathrm{BI}, \mathrm{BP}$ \& External environment factors (customer perspective on FDP \& impact of a global pandemic). The past literature was collected on these areas to get a better understanding of the topics.

\section{a) Business Intelligence}

A study on the implementation of $\mathrm{Bl}$ for the Malaysian Halal Food Manufacturing Industry for strategic performance management was able to conclude and understand the level of influence of critical success factors that can improve or limit the adoption of $\mathrm{BI}$ and organization financial performance [6]. Another study investigating De Lones and Mclean's Information systems success model on 12 public hospitals and the success factors that influence the $\mathrm{BI}$ stated that all the relationships such as information quality and system quality are positively related to user satisfaction. This research shows that this model has a good fit and a predictive value [7]. A study on $\mathrm{BI}$ solution for Food Industry to reduce the inventory level of Pakistan National Food concluded that BI system could be used to analyze data using effective dashboard more efficiently, as well as big data, can be handled with implementing data warehouse where data warehouse gives the flexibility to accommodate a large amount of data [8]. Another study conducted to understand how the implementation of $\mathrm{Bl}$ and analytics will help the organization to improve its $\mathrm{BP}$, proved that there is a positive relationship between the implementation of $\mathrm{BI}$ and Analytics in an organization to improve the BP. The firms, which are equipped with the ability to analyze web and social media data, have a higher relationship BP and $\mathrm{Bl}$ where the companies who collect data from sensors are outperforming those who are not collecting [9] A study to understand what are the critical success factors that influence the $\mathrm{Bl}$ in the Swedish market, stated that the findings show that all the respondents have a positive outlook regarding $\mathrm{BI}$, a suitable level of self-service $\mathrm{Bl}$ to the maximum varies depending on the respondents. BI suppliers promote a high level of selfservices to use the full potential of; $\mathrm{Bl}$ users and $\mathrm{BI}$ specialists/consultants want a more modest method, where the $\mathrm{Bl}$ is managed and used are not allowed the alter the business data as they need [10].

A study understanding the success factors that influence the $\mathrm{Bl}$ in the pharmaceutical companies of Pakistan stated that $\mathrm{BI}$ has a significant relationship with marketing performance. The four main success factors, strategic planning, knowledge management, technological innovation, and organizational support, have an impact on Bl success factors. The success of $\mathrm{BI}$ has a significant impact on market performance [11]. A study with the objectives of creating a conceptualization and discussing the dynamic capability of $\mathrm{Bl}$ and designing a framework for $\mathrm{Bl}$ concluded that the survey shows that the $\mathrm{BI}$ is considered as a tool or technology, which used to gather and analyze data and does not occur to be the only main factor in deciding on an organization. $\mathrm{Bl}$ will also improve organizational performance and help to come up with new business ideas and creating a new business procedure for business operations. The organization should focus on creating a strategic alignment of $\mathrm{Bl}$ and Business strategy of the organization [12]. Research conducted on $\mathrm{BI}$ application in Healthcare delivery in the USA proved that healthcare providers in a competitive market need a strong $\mathrm{BI}$ foundation to correlate, analyze, and visualize operational \& financial data. The BI Tools help healthcare providers to manage population health since nowadays, Technology plays a vital role in the healthcare industry [13]. 


\section{b) Business Performance}

A study conducted on the influence of BI capacity, network learning, and innovativeness on startup performances concluded that there is a positive effect among the variables, namely network learning, innovativeness and performances have an impact onBI capacities. Also, in the start-up's perspective, some attention should be taken on $\mathrm{BI}[14]$. Research on Marketing, Innovation, and BP of women entrepreneurs in the fashion industry, stated that that intelligent generation and innovation has a positive relationship between a firm's performances [15]. A study was conducted how the marketing orientation effects on BP on the Foodstuff industry, stated that marketing orientation is efficient creation of information, disseminating information \& the level of responsiveness to reach through information. These three factors are always related to customer, market \& competition [16]. Research on online retail store performance measurement was able to conclude that that information available, quality of the product, and product delivery are the factors most important in measuring the performance of the online retail store [17]. A study on the Impact of marketing strategy on BP of Small and Medium Enterprises (SMEs) stated that marketing strategies were significantly independent and joint predictor of $\mathrm{BP}$, despite that promotion has no positive effect on BP. Thus, the research confirms that combining different strategies provide functional benefits to consumers [18]. A study on BP for SMEs resulted in showing that subjective evaluations are important alternatives to objective measurement [19]. A study to understand the relationship that Employee satisfaction and customer satisfaction on financial performance concluded that there is a significant positive relationship between customer satisfaction and financial performance. Aslo it indicated that there is an indirect relationship between Organizational financial performance and employee satisfaction [20].

\section{c) External Environmental Factors}

\section{i. Customer Perspective on Food Delivery Platform}

Research on consumer behavior towards the utilization of online FDPs' stated that there is a huge demand for mobile food delivery application in the future. Also, it saves consumers time, and they would be able to have a wide range of selection among the available restaurants and most importantly customer has had the satisfaction of able to access the mobile technology and being informative. Thus, these developments are modernizing food delivery with a faster availability of food to their doorsteps [21]. Similar research on the impact of online food delivery apps on the restaurant business concluded that customer comfort and digital systems combined, helping FDPs' to sustain and develop. The organization that knows about colossal potential for development will endure by keeping their offer and their image dynamic in customers' minds through having delivered food and foodstuffs to their doorstep with well prepared to eat and less cost [22]. A study on evaluative collaborative consumption of food delivery services through web mining techniques stated that online FDP can be improved and could understand the different cultural existence in food preference and customers' level of satisfaction by analyzing customers' comments with text mining techniques [23]. Research on the influence of food delivery apps on the operations of the restaurant business concluded that there is an increase in sales when there is an increase in the usage of delivery apps and that restaurants should implement proper inventory management to deal with the demand [24]. An empirical study on consumer perception towards Online Food Ordering and Delivery Services concluded that Zomato (Online food delivery portal) stands top with gained most positive opinion among other service providers by their better on-time delivery and better discounts [25].

\section{ii. Impact of Global Pandemic (Covid-19)}

A study conducted on understanding the impact of Covid-19 on the expectation and outcomes of small businesses concluded that those small business firms are currently holding on to the small amount of money, which force them to take drastic measure on their business to cut expenses, to take a loan, which can increase their debt, and in the worst case to declare them bankrupted [26]. A study on the employees' wellbeing and adjustments in the current era of Covid19stated that that the impact that Covid-19 might have on the human resource will not be short-lived. The world can focus on forward-thinking and building based on assumption that we are currently not facing a single event, but this might create a new chain of events that leads to a new reality and new opportunities to which the scholars and practitioners should be attentive [27]. A study on understanding the macroeconomic scenario in Morocco, conclude that the overall result shows that economic condition will deteriorate, but socio-economic relation become closer [28]. A study on an emerging Business model in the Aviation industry Ultra Long Haul (ULH) in Covid-19 Outbreak stated that ULH is become more popular prior Covid era, and now, with the Covid outbreak has accelerated the use and acceptance of the point-to-point ULH approach. [29]. A study on how to manage the uncertain situation in terms of international business perspective in this global pandemic situation concluded that globalization changes how the world conducts business when a problem is faced for instances such as SARS, Ebola, and wars, etc. The Covid-19 crisis helps to review the organization's reactions and the organization's consequences; there are implications for international business managers and suggest directions for future research [30]. 


\section{d) Conceptual Framework}

The Conceptualization framework has been designed for the research where the BP for the organization is considered as a Dependent variable, and $\mathrm{BI}$ is considered as an Independent variable. External environmental factors are considered as a moderator variable. This conceptual framework will help to understand how does $\mathrm{BI}$ impact BP of FDP and how does the external environment will impact the BP while other factors remain the same.

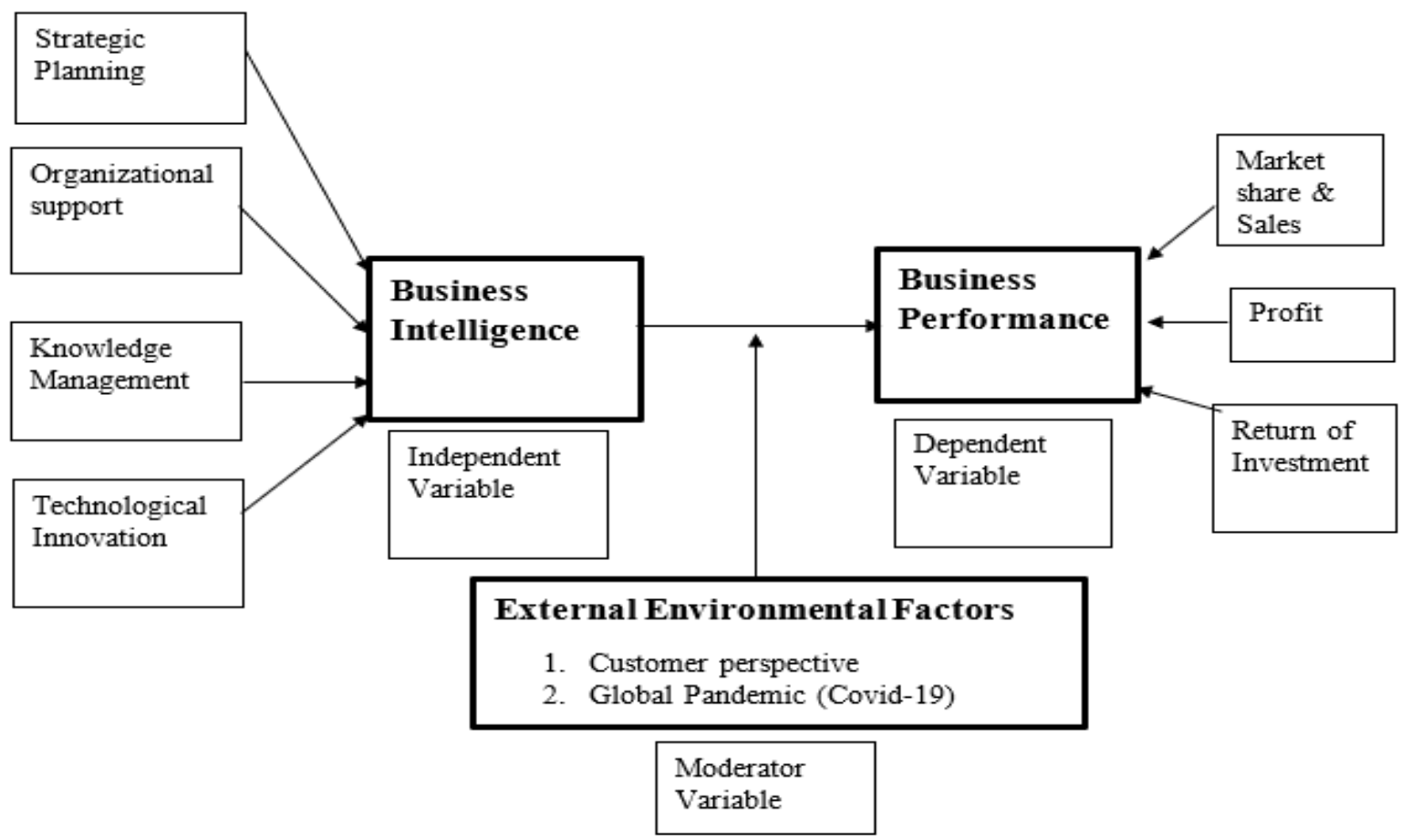

Figure 1: Conceptual Framework

\section{ili. Data and Methodology}

The current study is pursuing a deductive research approach or also known as a top-down approach, as this study is developed on rigorous literature review, and based on them, a hypothesis was developed, which will be answered after the data had been analyzed.

\section{a) Questionnaire 1-Employees' Perspective Questionnaire}

In selecting the sample for the FDP, the convenience-sampling method was decided to be used, which is a non-probability sampling method, and the sample will be Uber EATS and Pick Me Food. For the employee perspective survey, the sample size is based on the number of employees available in the $\mathrm{Bl}$ department, and received 178 responses for the questionnaire.

\section{b) Questionnaire 2 - Interview Questionnaire}

To understand how the FDP overcame the global pandemic, it was analyzed based on the responses given by the head of the $\mathrm{BI}$ department of Uber EATS and Pick Me Food. The answers for this will be gathered through an interview approach based on the questions developed. Also, the information gathered has indicated the importance of $\mathrm{BI}$ tools and methods that have been used by organizations. c) Questionnaire Questionnaire

3-Customer Perspective

Customers' perspective survey was conducted on the general population to understand how customer perspective impacts BP of FDP, and simple random sampling was used. And the acceptable responses received for this was 379 .

This flow chart helps reviewers to easily understand each step, which is going to be done under the methodology process in this study. 


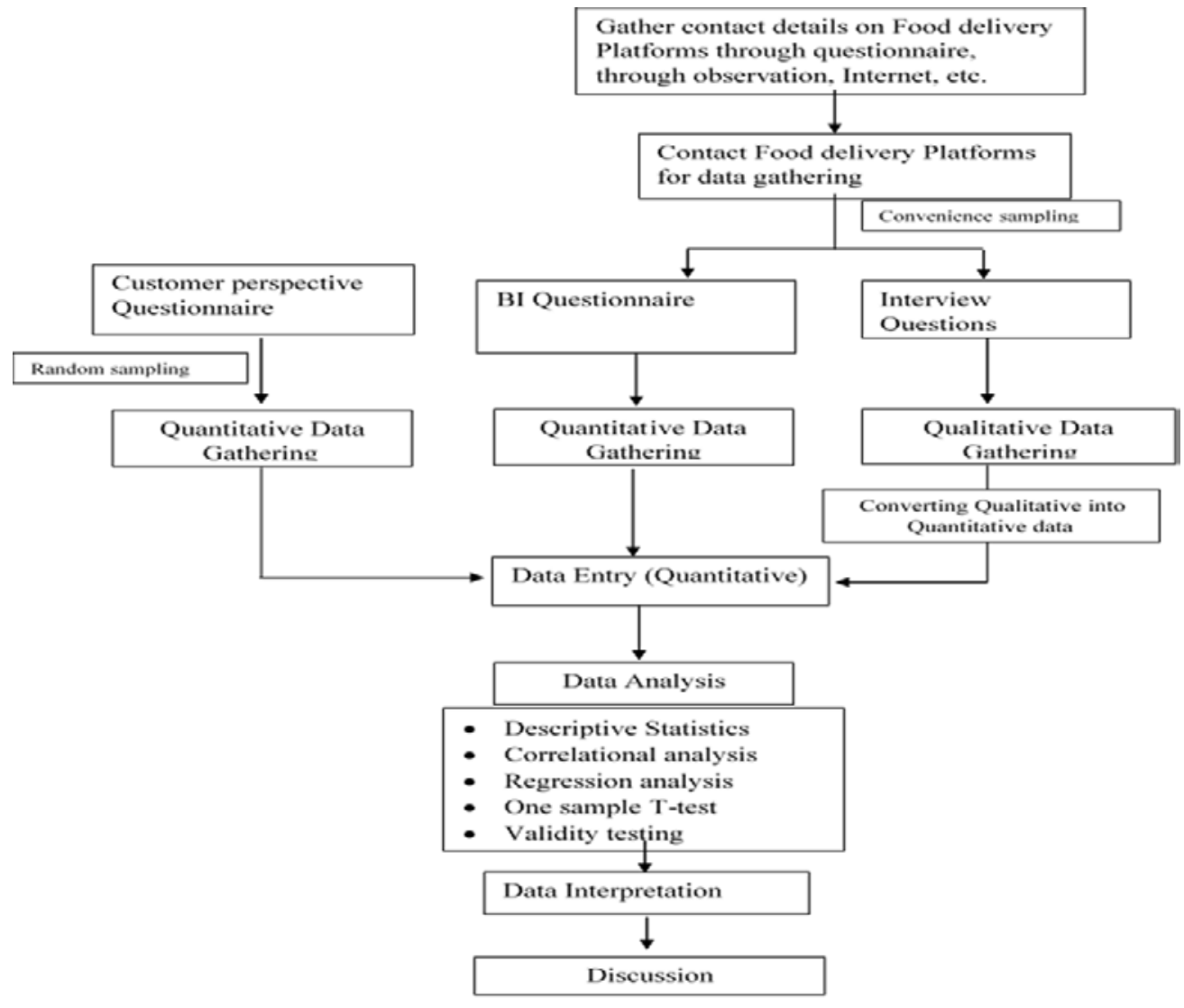

Figure 2: Methodology flowchat

After all the data are gathered, it will be analyzed using Statistical Package for Social Sciences (SPSS), and the hypothesis will be tested using the statistical significance of variance, correlation, and regression. For this study, Quantitative analysis will be made where descriptive statistics, Correlation analysis, Regression analysis, one paired T-test analysis \& validity testing.

\section{Results and Discussion}

a) Regression Analysis

The regression model is used to check the significant relationship between hypotheses. The equation that is used to check the regression between hypotheses is stated as below.

\section{Equation 1: Regression Equation}

\section{1. $\boldsymbol{Y}_{B I}=a I+\left(\beta 1 X_{S P}+\beta 2 X_{o s}+\beta 3 X_{K M}+\beta 4 X_{T I}\right)$ \\ 2. $\boldsymbol{Y}_{B P}=a 5+\beta 5 X_{B I}$}

Where,

$Y_{B I}=$ Business Intelligence $\beta 1 X_{S P}=$ Strategic Planning, $\beta 2 X_{O S}=$ Organizational Support $\beta 3 X_{K M}=$ Knowledge Management, $\beta 4 X_{T 1}=$ Technological Innovation. $Y_{B P}=$ Business Performance, $\beta 5 X_{B I}$ Business Intelligence.

Where $X_{S P} X_{O S} X_{K M} X_{T /}$ are independent variables and a dependent variable is $Y_{B I} B I$ in equation one, and $Y_{B P}=\mathrm{BP}$ and $X_{B I}=\mathrm{Bl}$ are dependent and independent variables respectively in equation two. Also, $\mathrm{a}=$ constant (a1 = constant values of independent variable 1,2,3,4 respectively) and $\beta=$ coefficient of independent variable.
The first four models show the relationship between the success factor of $\mathrm{BI}\left(X_{S P}, X_{O S}, X_{K M}\right.$ and $X_{T I}$ as independent variable) and $B I\left(Y_{B I}\right.$ as dependent variable) the fifth model shows the relationship between $\mathrm{BI}\left(X_{B 1}\right.$ as independent variable) and BP $\left(Y_{B P}\right.$ as dependent variable).

A model table has been drawn via SPSS output (regression) to check the relationship of each success factor as per the equation, which is stated above. That model table has five sub-model for the equation showed Equation 1. 
Table 1: Regression Model for Employee Perspective Survey

\begin{tabular}{|l|l|l|l|l|}
\hline Model & Constant Value & B & P- Value & Adjusted R-Value \\
\hline Model 1 & 1.063 & 0.696 & 0.000 & 0.491 \\
\hline Model 2 & 1.359 & 0.608 & 0.000 & 0.403 \\
\hline Model 3 & 1.066 & 0.698 & 0.000 & 0.488 \\
\hline Model 4 & 0.965 & 0.710 & 0.000 & 0.513 \\
\hline Model 5 & 0.913 & 0.749 & 0.000 & 0.542 \\
\hline
\end{tabular}

All five models have a lower P-Value than .05. Where businesses are considered as social science Based on the regression, the Adjusted R-Square value of all the models is greater than $30 \%$. Thus, it is concluded that all the five models are reliable since a

b) To understand the impact of success factors of $B I$ to $B P$

i. Strategic Planning impact on $B P$

Table 2: Strategic Planning to BP

\begin{tabular}{|l|l|l|l|l|l|}
\hline & $\begin{array}{l}\text { B- } \\
\text { Coefficient }\end{array}$ & $\begin{array}{l}\text { Standard } \\
\text { Error }\end{array}$ & $\begin{array}{l}\text { T- } \\
\text { Ratio }\end{array}$ & $\begin{array}{l}\text { P- } \\
\text { value }\end{array}$ & $\begin{array}{l}\text { Adjusted R R } \\
\text { Square }\end{array}$ \\
\hline Constant & 1.030 & 0.187 & 5.507 & 0.000 & \multirow{2}{*}{0.509} \\
\cline { 1 - 4 } Strategic Planning & 0.718 & 0.053 & 13.626 & 0.000 & \multirow{5}{|l}{} \\
\hline
\end{tabular}

The strategic planning coefficient is statistically significant, which shows that there is a strong relationship between strategic planning and BP. The greater $80 \%$ P-value shows the significant relationship between the success factor and $\mathrm{BI}$. Also, the result shows that each success factor has an impact on $\mathrm{BI}$ separately as well as collectively.

ii. Organizational Support impact on BP

Table 3: Organizational support to BP

\begin{tabular}{|l|l|l|l|l|l|}
\hline & $\begin{array}{l}\text { B- } \\
\text { Coefficient }\end{array}$ & $\begin{array}{l}\text { Standard } \\
\text { Error }\end{array}$ & $\begin{array}{l}\text { T- } \\
\text { Ratio }\end{array}$ & $\begin{array}{l}\text { P- } \\
\text { value }\end{array}$ & $\begin{array}{l}\text { Adjusted R } \\
\text { Square }\end{array}$ \\
\cline { 1 - 5 } Constant & 1.407 & 0.202 & 6.964 & 0.000 & \multirow{2}{*}{0.390} \\
\cline { 1 - 5 } $\begin{array}{l}\text { Organizational } \\
\text { Support }\end{array}$ & 0.607 & 0.057 & 10.723 & 0.000 & \\
\hline
\end{tabular}

Independent Variable $=$ Organizational Support, Dependent Variable $=\mathrm{BP}$

The Organizational Support coefficient is statistically significant, which shows that there is a strong relationship between Organizational Support and adjusted R-square value is 0.509 , which shows $51 \%$ of variation between $\mathrm{BP}$ and strategic planning done by the organization.
BP. The adjusted R-square value is 0.390 , which shows $39 \%$ of variation between BP and Organizational Support. 
iii. Knowledge Management impact on BP

Table 4: Knowledge Management to BP

\begin{tabular}{|c|c|c|c|c|c|}
\hline & $\begin{array}{l}\text { B- } \\
\text { Coefficient }\end{array}$ & $\begin{array}{l}\text { Standard } \\
\text { Error }\end{array}$ & $\begin{array}{l}\text { T- } \\
\text { Ratio }\end{array}$ & $\begin{array}{l}\text { P- } \\
\text { value }\end{array}$ & $\begin{array}{ll}\text { Adjusted } & R \\
\text { Square } & \end{array}$ \\
\hline Constant & 1.245 & 0.204 & 6.118 & 0.000 & \multirow[b]{2}{*}{0.422} \\
\hline $\begin{array}{l}\text { Knowledge } \\
\text { Management }\end{array}$ & 0.659 & 0.058 & 11.434 & 0.000 & \\
\hline
\end{tabular}

Independent Variable $=$ Knowledge Management, Dependent Variable $=\mathrm{BP}$

The Knowledge Management coefficient is statistically significant, which shows that there is a strong relationship between Knowledge Management

iv. Technology impact on BP and BP. The adjusted R-square value is 0.422 , which shows $42.2 \%$ of variation between BP and Knowledge Management in the organization.

Table 5: Technology Impact on BP

\begin{tabular}{|l|l|l|l|l|l|}
\hline & $\begin{array}{l}\text { B- } \\
\text { Coefficient }\end{array}$ & $\begin{array}{l}\text { Standard } \\
\text { Error }\end{array}$ & $\begin{array}{l}\text { T- } \\
\text { Ratio }\end{array}$ & $\begin{array}{l}\text { P- } \\
\text { value }\end{array}$ & $\begin{array}{l}\text { Adjusted R } \\
\text { Square }\end{array}$ \\
\hline Constant & 1.029 & 0.194 & 5.308 & 0.000 & \multirow{2}{*}{0.491} \\
\cline { 1 - 4 } $\begin{array}{l}\text { Technological } \\
\text { Innovation }\end{array}$ & 0.705 & 0.054 & 13.153 & 0.000 & \\
\hline
\end{tabular}

Independent Variable $=$ Technology, Dependent Variable $=\mathrm{BP}$

The Technology coefficient is statistically significant, which shows that there is a strong relationship between Technology and BP. The adjusted
R-square value is 0.491 , which shows $49.1 \%$ of variation between BP and Technology in the organization.

Hypothesis related testing for the above mentioned is stated below in the table.

Table 6: Hypothesis Testing Results

\begin{tabular}{|c|l|c|}
\hline Hypothesis & \multicolumn{1}{|c|}{ Hypothesis } & Status \\
\hline $\mathbf{1}$ & $\begin{array}{l}\mathrm{H}_{0}-\text { There is no relationship between strategic planning } \\
\text { and BP. } \\
\mathrm{H}_{\mathrm{a}}-\text { There is a significant relationship between strategic } \\
\text { planning and BP. }\end{array}$ & $\begin{array}{c}\text { Accept Alternate } \\
\text { Hypothesis }\end{array}$ \\
\hline $\mathbf{2}$ & $\begin{array}{l}\mathrm{H}_{0}-\text { There is no relationship between Organizational } \\
\text { Support and BP. } \\
\mathrm{H}_{\mathrm{a}}-\text { There is a significant relationship between } \\
\text { Organizational Support and BP. }\end{array}$ & $\begin{array}{c}\text { Accept Alternate } \\
\text { Hypothesis }\end{array}$ \\
\hline $\mathbf{3}$ & $\begin{array}{l}\mathrm{H}_{0}-\text { There is no relationship between Knowledge } \\
\text { Management and BP. }\end{array}$ & $\begin{array}{c}\text { Accept Alternate } \\
\text { Hypothesis }\end{array}$ \\
\hline $\mathbf{H}$ Knowledge Management and BP & $\begin{array}{c}\text { Accept Alternate } \\
\text { Hypothesis }\end{array}$ \\
\hline & $\begin{array}{l}\mathrm{H}_{0}-\text { There is no relationship between Technological } \\
\text { Innovation and BP. } \\
\mathrm{H}_{\mathrm{a}}-\text { There is a significant relationship between } \\
\text { Technological Innovation and BP }\end{array}$ & \\
\hline
\end{tabular}

Since the success factors of $\mathrm{Bl}$ show a significant relationship between $\mathrm{BP}$, this also proves that
$\mathrm{BI}$ has a significant relationship with BP. This statement can be statistically proven using this table. 
v. Bl Impact on BP

Table 7: $\mathrm{BI}$ to BP

\begin{tabular}{|l|l|l|l|l|l|}
\hline & $\begin{array}{l}\text { B- } \\
\text { Coefficient }\end{array}$ & $\begin{array}{l}\text { Standard } \\
\text { Error }\end{array}$ & $\begin{array}{l}\text { T- } \\
\text { Ratio }\end{array}$ & $\begin{array}{l}\text { P- } \\
\text { value }\end{array}$ & $\begin{array}{l}\text { Adjusted R } \\
\text { Square }\end{array}$ \\
\cline { 1 - 4 } Constant & 0.913 & 0.183 & 4.977 & 0.000 & \multirow{2}{*}{0.542} \\
\cline { 1 - 4 } & 0.749 & 0.051 & 14.554 & 0.000 & \\
\hline
\end{tabular}

Independent Variable $=\mathrm{BI}$, Dependent Variable $=\mathrm{BP}$

The table shows that there is a significant relationship between $\mathrm{Bl}$ and $\mathrm{BP}$. The $\mathrm{Bl}$ coefficient is statistically significant, which shows that there is a strong relationship between $\mathrm{Bl}$ and BP. The adjusted R- square value is 0.542 , which shows $54.2 \%$ of variation between $\mathrm{BP}$ and $\mathrm{Bl}$ in the organization. as follows,

The Regression Equation between $\mathrm{Bl}$ and $\mathrm{BP}$ is

Equation 2: Regression Equation for BI vs. BP

$$
Y_{B P}=0.913+0.749 X_{B I}
$$

Equation 2 shows that the coefficient value shows that when $\mathrm{BI}$ increases by one unit, the $\mathrm{BP}$ will increase by 0.749 units. When no $\mathrm{Bl}$ is available in the FDP, the BP will be 0.913 units.

vi. Success Factor of $B I$ on $B P$

Table 8: Success Factor of BI on BP

\begin{tabular}{|c|c|c|c|c|c|}
\hline & $\begin{array}{l}\text { B- } \\
\text { Coefficient }\end{array}$ & $\begin{array}{l}\text { Standard } \\
\text { Error }\end{array}$ & $\begin{array}{l}\text { T- } \\
\text { Ratio }\end{array}$ & $\begin{array}{l}\mathrm{P} \text { - } \\
\text { value }\end{array}$ & $\begin{array}{l}\text { Adjusted } \\
\text { R Square }\end{array}$ \\
\hline Constant & 0.434 & 0.193 & 2.249 & 0.026 & \multirow{5}{*}{0.598} \\
\hline Strategic Planning & 0.278 & 0.083 & 3.335 & 0.001 & \\
\hline Organizational Support & 0.152 & 0.066 & 2.300 & 0.023 & \\
\hline Knowledge Management & 0.166 & 0.073 & 2.271 & 0.024 & \\
\hline Technological Innovation & 0.290 & 0.076 & 3.835 & 0.000 & \\
\hline
\end{tabular}

Independent Variable = Strategic Planning, Organizational Support, Knowledge

Management, Technological Innovation Dependent Variable= BI

The table shows that there is a significant relationship between the Success Factors of $\mathrm{Bl}$ and $\mathrm{BP}$. Success Factors of the $\mathrm{Bl}$ coefficient is statistically significant, which shows that there is a strong relationship between $\mathrm{Bl}$ and $\mathrm{BP}$. The adjusted R-square

Equation 3: Regression Equation for Success factors of BI vs. BP

$$
Y_{B P}=0.434+\left(0.278 X_{S P}+0.152 X_{O S}+0.166 X_{K M}+0.290 X_{T I}\right)
$$

Equation 3 shows that when Strategic Planning increases by one unit, the BP will increase by 0.278. When Organizational Support increase by one unit, the BP will increase by 0.152 . When Knowledge Management increases by one unit, the BP will increase by 0.166 . When Technological Innovation increase by one unit, the BP will increase by 0.290 , and when there is no involvement in the success factors of $\mathrm{Bl}$ in FDP the BP will be 0.434 . value is 0.598 , which shows $59.8 \%$ of variation between $\mathrm{BP}$ and $\mathrm{BI}$ in the organization.

The Regression Equation for between Success Factors of $\mathrm{Bl}$ and $\mathrm{BP}$ is as follows, c) To identify the $\mathrm{BI}$ methods and tools is used by FDPs' in Sri Lanka

The interview responders say that the $\mathrm{Bl}$ Deployment they have in their respective organization is an enterprise-wide $\mathrm{BI}$ deployment based on corporate IT. They have an integrated BI system that can be used by every employee in the organization. Pick Me Foods uses open-source Bl Tools such as Modo, whereas Uber EATS use in-house BI Tools such as Uber's 
Movement and Uber's BI Suite. These tools are used to make a business decision more accurate and datadriven to improve the success of each business decision that will be made. These organizations use multiple tools that guide users with different skills to derive valuable business insights using data.

Business intelligence is applied in the organization for several business operations detecting fraud using complaint data, visualization, making new business promotion and location intelligence, etc., which help improve organizational performance. These organizations use the data for predicting time for preparation and delivery, natural language processing (NLP), Text mining, recommending restaurant/ foods to a customer, forecasting demand and supply for each restaurant, optimizing spending patterns of the customer for giving better offers and dynamic pricing, etc. for instance,

1. Customer Rating system - This rating system is used by the FDP to create a trust in customers on the quality of the service that is delivered by the rider as well as the organization, and the rating on the customer will help the organization customer relationship management (CRM) to segment the customers.

2. Surge pricing- FDP uses this pricing when they must deliver the Food to the customers in distant locations or order, made in an off-peak hour, where the cost for delivery will be increased. FDP has developed their algorithms to predict the amount that they can charge for the delivery. This system will help the rider to make more sustainable profits in their delivery services as per requirements.

d) To identify the effect that external environmental factors have on $B P$

\section{i. Customer Perception}

From the 400 responses received for the questionnaire, 21 incomplete responses were there; therefore, 379 of the responses were used for the analysis purposes. The survey's demographic question found a relatively higher number of males (54.6\%) than females (45.4\%). Most of the respondents were between the age group of $20-25(49.9 \%)$ and $26-30(38.8 \%)$. Frequently used FDP Uber EATS had $73.1 \%$, and Pick Me Foods had only $26.9 \%$. This Customer Perception comparison shows as follows,

Table 9: Customer Perception Comparison

\begin{tabular}{|l|c|c|c|}
\hline Customer perception & $\begin{array}{c}\text { PickMe } \\
\text { Food }\end{array}$ & UberEATS & $\begin{array}{c}\text { Better } \\
\text { Performer }\end{array}$ \\
\hline I feel This application is very easy to use & 3.90 & 4.05 & UberEATS \\
\hline I feel I can control the decision making & 3.88 & 3.97 & UberEATS \\
\hline I feel this application is reliable to use & 3.98 & 3.97 & PickMe Food \\
\hline I feel this application is user friendly & 3.95 & 4.06 & UberEATS \\
\hline $\begin{array}{l}\text { I feel I am provided with the required information } \\
\text { when I make a purchase }\end{array}$ & 3.91 & 3.98 & UberEATS \\
\hline I feel that this application provides quicker delivery & 3.78 & 3.93 & UberEATS \\
\hline $\begin{array}{l}\text { I feel that this application provides better and } \\
\text { frequent promotions }\end{array}$ & 3.78 & 3.94 & UberEATS \\
\hline $\begin{array}{l}\text { I feel that this application covers a variety of } \\
\text { cuisines }\end{array}$ & 3.88 & 4.06 & UberEATS \\
\hline $\begin{array}{l}\text { I feel that this application has a high amount of } \\
\text { service providers }\end{array}$ & 3.88 & 4.03 & UberEATS \\
\hline $\begin{array}{l}\text { I feel that this application has service providers with } \\
\text { good attitudes }\end{array}$ & 3.96 & 4.00 & UberEATS \\
\hline $\begin{array}{l}\text { I feel that this application has highly accurate } \\
\text { location trackers }\end{array}$ & 3.18 & 3.97 & UberEATS
\end{tabular}

To test hypothesis five, Average Sales and Customer Perception on FDP were tested, the average sales values are used for Testing Hypotheses. For this testing, a Non-parametric test (Independent Samples
Kruskal-Wallis test) is used. The reason for using this non-parametric test is the data is not normally distributed, and the variable used is nominal and ordinal variables. 
Table 10: Hypothesis test for external environmental factors

\begin{tabular}{|l|l|c|c|c|}
\multicolumn{5}{|c|}{ Hypothesis Test Summary } \\
\hline 1 & \multicolumn{1}{|c|}{ Null Hypothesis } & Test & Significance & Decision \\
\hline 1 & $\begin{array}{l}\text { The distribution of } \\
\text { Average_Score_in_Customer_- } \\
\begin{array}{l}\text { Perception is the same across } \\
\text { categories of Average_Sales. }\end{array}\end{array}$ & $\begin{array}{c}\text { Independent-Samples } \\
\text { Kruskal-Wallis Test }\end{array}$ & .000 & $\begin{array}{c}\text { Reject the null } \\
\text { hypothesis }\end{array}$ \\
\hline
\end{tabular}

Asymptotic significances are displayed. The significance level is .05 .

$\mathrm{H}_{0^{-}}$- There is no relationship between external environmental factors and BP.

$H_{a}-$ There is a significant relationship between external environmental factors and BP.

And the result showed that the significance value of the test is less than 0.05 , thereby accepting the alternate hypothesis stating there is a significant relationship between external environmental factors and BP.

e) How are the FDP utilizing $B /$ to face an uncertain situation like the global pandemic (Covid-19)?

The Current Global Pandemic is seen as an opportunity as well as a threat for the FDP since the disease spread at a higher rate, which created a situation of lockdown where many essential businesses were shut down. For example, groceries and medicine were closed to reduce the spreading virus around the country. The FDPs saw a business opportunity to fill the gap of supplying essential products to the consumers by collaborating with suppliers to deliver the products online. The organization must also have to face problems that are related to delivery where the customer feared to order food from FDP since the customers feared how the food is produced and delivered to them.

Pick Me Foods Interview respondent also stated that the real challenge that they faced was how to gain the confidence of customer regarding the delivery of food, and once the FDP are relieved from the curfew, they made sure to comply with the rules and regulation to ensure the safety of the riders and the customers.

\section{Conclusion}

The findings of this study show the success factors of BI has a significant impact on the BP of FDPs' which is seen evident in the results from the employee perspective survey where Strategic planning, Organizational Support, Knowledge management, Technological innovation are statistically significant for the BP of FDP since the p-value of each analysis is less than 0.05 .

The interview respondents feel that the current national and international climate that has been created due to the spread of Covid-19 at a higher rate has created an opportunity in terms of delivering essential products through their application as well as a threat for FDPs' where the organization have to build trust among their customers both the restaurants and consumers their delivery process to prevent them getting infected by disease on the point of contact through delivery. The FDPs' delivery riders were made to adhere to the government regulation on testing, non-contactless delivery to bring back the trust in the organization.

In terms of limitation faced, Covid-19 pandemic impacted the data collection process, and the data collected from the organization is sensitive for the organization were reluctant to provide more information regarding the study and unable find literature for external environmental factor - Covid-19 was another limitation since the global pandemic is still happening.

The future study opportunities that can be seen through this study, the conceptual framework can be applied to other industries to understand how $\mathrm{BI}$ can impact the BP of the business organizations in a specific industry. Future research can also be conducted on how FDPs' in different countries perform and how the other external environmental factors (PESTLE) influence business performance.

The future study can also be conducted on methods that are used in the tech companies, for instance, technologies like Location intelligence, sentiment analysis, etc, and how they use big data to gain insights from these methods. This study can add value by filling the knowledge gaps in the method applied in the new business world in this current industrial revolution of Industrial revolution 4.0, where future studies can include objective measures in numerical methods to evaluate the BP of FDP. Also, in FDPs' context, the term $\mathrm{BI}$ is no longer considered since it is evolving towards Data Science and Artificial Intelligence (Al) as future research can be done including these technical evolvements.

\section{References Références Referencias}

1. P. Fultz, "Staying Fresh in the restaurant industry Insights from KPMG's Annual Resturants Financial executives Share Forum," KPMG, 2017.

2. C. Hirschberg, A. Rajko, T. Schumacher and M. Wrulich, "The changing market for food delivery," Mckinsey \& Company, 2016.

3. M. Muthukumar and Karthikeyan, "Business Intelligence Market Trends and Growth in Enterprise Business," International Journal on Recent and Innovation Trends in Computing and 
Communication, vol. Vol.4, no. 3, pp. 188-192, 2016.

4. Adaderana. Ik, "BizEnglish. Ada Derana.Ik," 2019. [Online]. Available: http://bizenglish.Adaderan a.Ik/uber-eats-delivers-over-3-million-orders-within12-months-in-sl/. [Accessed 1204 2020].

5. G. Fuldner, "Uber," 2020. [Online]. Available: https://www.uber.com/en-LK/newsroom/covid-19safety-update/. [Accessed 1005 2020].

6. J. Mailasan, M. K. Abdul, A. R. Fadhlur and A. Abu, "Implementation of business intelligence framework for Malaysian halal food manufacturing industry," Management Science Letters, vol. 8, pp. 1059-1076, 2018.

7. R. Gaardboe, N. Sandalgaard and T. Nyvang, "An assessment of business intelligence in public hospitals," International Journal of Information Systems and Project Management, vol. 5, no. 4, pp. 5-18, 2017.

8. Raheela, H. Saman and M. Sukaina, "Business Intelligence Solution for Food Industry," Journal of Basic \& Applied Sciences, vol. 13, pp. 442-447, 2017.

9. M. D. Kakhki and P. Palvia, "Effect of Business Intelligence and Analytics on Business Performance," Americas Conference on Information Systems, San Diego, vol. 22, 2016.

10. J. Holmqvist, "Business Intelligence Critical Factors for BI Success," 2016.

11. Nawaz, "The Perceived Impact of Business Intelligence Tools on Marketing Success," pp. 1-55, 2015.

12. M. Olszak, "Towards an Understanding Business Intelligence. A Dynamic Capability-Based Framework for Business Intelligence," Federated Conference on Computer Science and Information Systems, no. 2, pp. 1103-1110, 2014.

13. Noushin, K. Lori and K. Jean-Pierre, "The Impact of Business Intelligence on Healthcare Delivery in the USA," Interdisciplinary Journal of Information, Knowledge, and Management, vol. 9, pp. 117-130, 2014.

14. Nuno and C. Arnaldo, "The influence of Business Intelligence capacity, network learning and innovativeness on startups performance," Journal of Innovation \& Knowledge, vol. 4, pp. 139-145, 2019.

15. A. Patrick, A. C. George, A. George, A. Matilda and B. Ernestina, "Market Orientation, Innovation and Business Performance:Insight from Womenpreneurs in the Fashion Industry in Ghana," Journal of Creativity and Business, vol. 4, pp. 5-27, 2018.

16. Š. Simona, T.-P. Janka, N. Gabriela and D. Jaroslav, "Effect of Marketing Orientation on Business Performance: A Study from Slovak Foodstuff Industry," Procedia Economics and Finance, vol. 34, pp. 622-629, 2015.
17. K. Singh and N. Anand, "A Study on Performance Measurement of Online Retail Stores," Asian Academic Research Journal of Multidiscplinary, vol. 1, no. 19, pp. 672-692, 2014.

18. Gbolagade, Adesola M.A and Oyewale I.O, "Impact of Marketing Strategy on Business Performance A Study of Selected Small and Medium Enterprises (Smes) In Oluyole Local Government, Ibadan, Nigeria.," IOSR Journal of Business and Management, vol. Vol.4, no. 11, pp. 59-66, 2013.

19. N. Perera and S. N. '. Zulkiffli, "A literature analysis on business performance for SMES - subjective or objective measures?," SIBR Conference on Interdisciplinary Business and Economics Research, pp. 1-9, 2011.

20. G. Chi and D. Gursoy, "Employee satisfaction, customer satisfaction, and financial performance: An empirical examination," International Journal of Hospitality Management, vol. 28, pp. 245-253, 2009.

21. P. Chetan, R. Sahilesh, S. Aprita and D. Numgay, "Journal of Theoretical and Applied Information Technology," Understanding Consumer Behavior Toward Utilization of Online Food Delivery Platforms, vol. Vol.19, no. 16, pp. 4353-4365, 2019.

22. G. Mitali, "A Study on Impact of Online Food delivery app on Restaurant Business special reference to zomato and swiggy," IJRAR- International Journal of Research and Analytical Reviews, vol. 6, no. 1, pp. 889-893, 2019.

23. Juan, G. Wilmer, B. Phillip, S. Gopal, C. Steven A., Y. Leidy and R. Alejandro, "Evaluation of collaborative consumption of food delivery services through web mining techniques," Journal of Retailing and Consumer Services, vol. 46, pp. 4550, 2019.

24. S. Das and D. Ghose, "Influence of Online Food Delivery Apps on the Operations of the Resturants Business," International Journal Of Scientific \& Technology Research, vol. 8, no. 12, pp. 1372-1377, 2019.

25. Jyotishman, "Consumer Perception Towards 'Online Food Ordering And Delivery Services':An Empirical Study," Journal of Management (JOM), vol. Vol.5, no. 5, pp. 155-163, 2018.

26. Bartik, M. Bertrand, Z. Cullen, E. Glaeser and M. Luca, "The impact of COVID-19 on small business outcomes and expectations," Proceedings of the National Academy of Sciences of the United States of America, vol. 117, no. 30, p. 17656-17666, 2020.

27. J. Carnevale and I. Hatak, "Employee adjustment and well-being in the era of COVID-19: Implications for human resource management," Journal of Business Research, vol. 116, pp. 183-187, 2020.

28. Z. Firano and F. A. Fatine, "The COVID-19: macroeconomics scenarii and role of containment in Morocco," One Health, vol. 10, pp. 1-8, 2020. 
29. L. B. Bauer, D. Bloch and R. Merkert, "Ultra LongHaul: An emerging business model accelerated by COVID-19," Journal of Air Transport Management, vol. 89, 2020.

30. P. Sharma, T. Leung, R. P. Kingshott, N. S. Davcik and S. Cardinali, "Managing uncertainty during a global pandemic: An international business perspective," Journal of Business Research, vol. 116, pp. 188-192, 2020.

31. A. M. Sundjaja, "Implementation Of Business Intelligence On Banking, Retail, And Educational Industry," International Journal of Communication \& Information Technology, vol. Vol.7, no. 2, p. 65-70, 2013.

32. S. S. Soumya and S. Kalyani, "Allied Market Research," 2017. [Online]. Available: https://w ww.alliedm arketresearch.com/food-delivery-mobileapplication-market. [Accessed 1204 2020].

33. Echelon, "Echelon.Ik," 2019. [Online]. Available: https://echelon.Ik/dealing-with-the-gig-economy/. [Accessed 124 2020].

34. Forbes, "Forbes.com," 2019. [Online]. Available: https://www.forbes.com/sites/sarwantsingh/2019/09 /09/the-soon-to-be-200b-online-food-delivery-is-rap idly-changing-the-global-foodindustry/\#7d360ddcb1bc. [Accessed 1204 2020].

35. T. B. Amoako, "The importance of Business Intelligence as a decision-making tool: case study electricity company of Ghana (E.C.G)," 2013.

36. S. Adis and S. S. Klaus, "Customers' Expectations and Needs in the Business Intelligence Software Market," Journal of Intelligence Studies in Business, vol. 2, pp. 5-20, 2012.

37. K. Hartl, O. Jacob, F. L. Mbep, A. Budree and L. Fourie, "The Impact of Business Intelligence on Corporate Performance Management," Hawaii International Conference on System Sciences, vol. 49, pp. 5042-5051, 2016.

38. J. C. Naranjo-Valencia, D. Jiménez-Jiménez and R. Sanz-Valle, "Studying the links between organizational culture,innovation, and performance in Spanish companies," Revista Latinoamericana de Psicología, vol. 48, pp. 30-41, 2016.

39. A. Fyall, S. Singh and K. Appiah-Adu, "Marketing effectiveness and business performance in the financial service industry," Journal of Services Marketing, vol. 15, no. 1, pp. 18-34, 2001.

40. Y. M. M. Ernie, O. S. Mohd, O. Yuhanis and Y. R. M. Ahmad, "The Study on the Application of Business Intelligence in Manufacturing: A Review," International Journal of Computer Science Issues, vol. 10, pp. 317-324, 2013.

41. M. Hannula and V. Pirttimaki, "Business intelligence empirical study on the top 50 Finnish companies," Journal of American Academy of Business, Cambridge, vol. 2, no. 2, pp. 593-599, 2003.
42. P. Venter and D. Tustin, "The availability and use of competitive and business intelligence in South African business organisations," Southern African Business Review, vol. 13, no. 2, pp. 88-117, 2009.

43. S. M. Alagoza and H. Hekimoglu, "A study on tam: analysis of customer attitudes in online food ordering system," Procedia-Social and Behavioral Sciences, vol. 62, p. 1138-1143, 2012.

44. V. I. Kanteti, "Innovative strategies of startup firms in India - A study on online food delivery companies in India.," International Research Journal of Management Science \& Technology, vol. 9, no. 3, pp. 17-23, 2018.

45. F. Hossain and A. O. Adelaja, "Consumers' Interest in Alternative Food Delivery Systems:Results from a Consumer Survey in New Jersey," Journal of Food Dis\&ibution Research, pp. 49-67, 2009.

46. H. Lan, L. Ya'nan and W. Shuhua, "Improvement of Online Food Delivery Service Based on Consumers' Negative Comments," Canadian Social Science, vol. 12, no. 5, pp. 84-88, 2016.

47. H. Sethu and B. Saini, "Customer Perception and Satisfaction on Ordering Food via Internet, a Case on Foodzoned.Com, in Manipal," Proceedings of the Seventh Asia-Pacific Conference on Global Business, Economics,Finance and Social Sciences, pp. 15-17, 2016.

48. F. Esteban, I.-A. Susana, L.-L. Vicente, R.-R. Marcos and F.-J. Carlos M., "Firm and industry effects on small, medium-sized and large firms' performance," BRQ Business Research Quarterly, vol. 22, pp. 2535, 2019.

49. P. Neha and G. Sakina, "A study on customer's attitude and perception towards digital food app services," Amity Journal of Management, 2017.

50. M. Cavusoglu, "Electric Commerce and Turkish Patterns of Online Food Delivery System," IYUD, vol. 3, no. 1, pp. 45-61, 2012.

51. T. Chee-Sok, Y.-W. Sim and W. Yeoh, "A maturity model of enterprise business intelligence," Communications of the IBIMA, vol. 2011, pp. 1-9, 2011.

52. S. Negash, "Business Intelligence," Communications of the Association for Information Systems, vol. 13, pp. 177-195, 2004.

53. V. C. Sern Yeo, S.-K. Goh and S. Rezaei, "Consumer experiences, attitude and behavioral intention toward online food delivery (OFD) services," Journal of Retailing and Consumer Services, vol. 35, pp. 150-162, 2017.

54. "City Population," 2019. [Online]. Available: https://www.citypopulation.de/en/srilanka/prov/admi n/1_western/. [Accessed 0609 2020].

55. "Survey Monkey," [Online]. Available: https://www surveymonkey.com/mp/sample-size-calculator/. [Accessed 0609 2020]. 
56. M. J. Chorneukar, "To Study the Customer Perceptions of Electronic Food Ordering," 2014.

57. A. R. A. Singh, S. Pathan and V. Kanade, "Online Food Ordering System," International Journal of Computer Applications, vol. 180, no. 06, pp. 22-24, 2017.

58. G. See-Kwong, N. Soo-Ryue, W. Shiun-Yi and C. Lily, "Outsourcing to Online Food Delivery Services: Perpective of F\&B Business Owner," Journal of Internet Banking and Commerce, vol. 22, no. 2, 2017.

59. S. E. Kimes, "The Current State of Online Food Ordering in the U.S. Restaurant Industry," Cornell Hospitality Report, vol. 11, no. 17, pp. 6-18, 2011.

60. B. Dinter, "The Maturing of a Business Intelligence Maturity Model," 2012

61. G. Pigatto, J. G. d. C. F. Machado, A. d. S. Negreti and L. M. Machado, "Have you chosen your request? Analysis of online food delivery companies in Brazil," British Food Journal, vol. 119, no. 3, pp. 639-657, 2017.

62. S. Kraus, T. Clauss, M. Breier, J. Gast, A. Zardini and V. Tiberius, "The economics of COVID-19: initial empirical evidence on how family firms in five European countries cope with the corona crisis," International Journal of Entrepreneurial Behavior \& Research, 2020.

63. UberEATS, "Daily FT," 2019. [Online]. Available: http://www.ft.Ik/front-page/Uber-Eats-serves-over-3m-meals-in-first-year-to-expand-SL-investment/44687814. [Accessed 1204 2020]. 